\title{
A MULTI-CRITERIA DECISION-MAKING APPROACH THAT COMBINES FUZZY TOPSIS AND DEA METHODOLOGIES
}

\author{
O. Taylan $^{1 *}$, H. Alidrisi ${ }^{2} \& M$. Kabli $^{3}$ \\ Department of Industrial Engineering \\ Faculty of Engineering \\ King Abdulaziz University, Saudi Arabia. \\ 1otaylan@kau.edu.sa, ²hmalidrisi@kau.edu.sa, ${ }^{3}$ mkabli@kau.edu.sa
}

\begin{abstract}
Employee selection is a multi-criteria decision-making (MCDM) problem for selecting suitable applicants from a ready pool. The selection aims to make use of their knowledge, relevant skills, and other characteristics to perform a specific job. The aim of this study is to develop a systematic approach for selecting the best candidates among the air traffic controllers (ATCS) for aviation in Saudi Arabia. Three integrated methods were employed for decision-making in this study. First, a fuzzy decision tree was applied to determine the criteria weights, then the fuzzy Technique for Order Preference by Similarity to Ideal Solution (TOPSIS) was employed to rank the attributes. In the last step, the Data Envelopment Analysis (DEA) was used to transform the qualitative variables into quantitative equivalences. A survey was conducted by national and international decisionmakers to elicit the necessary information on the criteria and sub-criteria of the air traffic control system. The decision problem was formulated by employing five criteria and ten applicants. The relationship between the fuzzy TOPSIS and fuzzy-weighted average was very positive for decision-making. The outcomes of the fuzzy TOPSIS and DEA encouraged the development of a decision support system for the selection of ATCs.
\end{abstract}

\section{OPSOMMING}

Die kies van werknemers vanuit ' $n$ lys van gepaste aansoeke is ' $n$ multi-kriteria besluitnemingsprobleem. Die seleksie se doel is om gebruik te maak van die potensiële werknemers se relevante vaardighede en ander eienskappe om ' $n$ spesifieke taak te verrig. Die doel van hierdie navorsing is om ' $n$ sistematiese benadering, om die beste kandidate vir lugruimbeheerderposisies in Saoedi Arabië te identifiseer, te ontwikkel. Drie geïntegreerde metodes is ingespan vir die besluitneming in hierdie studie. Eerstens is ' $n$ wasige besluitnemingsboom toegepas om die kriteria gewigte te bepaal. Daarna is die wasige tegniek van Orde Voorkeur deur Ooreenkoms tot die Ideale Oplossing toegepas om die kenmerke te rangskik. Laastens is die Data Omvangs Analise gebruik om die kwalitatiewe veranderlikes tot kwantitatiewe gelykhede om te skakel. ' $n$ Peiling is onder nasionale en internasionale besluitnemers geneem om die noodsaaklike inligting rakende die kriteria en sub-kriteria van die lugruimbeheerstelsel te bepaal. Die besluitnemingsvraagstuk is geformuleer deur vyf kriteria en tien aansoekers in te span. Die verhouding tussen die wasige Orde Voorkeur deur Ooreenkoms tot die Ideale Oplossing en wasig-geweegde gemiddeld was besonder positief vir besluitneming. Die resultate van die wasige Orde Voorkeur deur Ooreenkoms tot die Ideale Oplossing en die Data Omvangs Analise moedig die ontwikkeling van ' $n$ besluitneming ondersteuningstelsel vir lugruimbeheerders aan.

Corresponding author 


\section{$1 \quad$ INTRODUCTION}

Employee selection is an unfolding multi-criteria decision problem. Inadequate traditional methods are still commonly used around the world for solving problems. Theory and methodology in the literature have been devoted to understanding the cross-cultural personnel selection problem [1]. Employee selection systems are usually very complex because they must mirror today's realities while also considering the future.

This study offers a new approach for selecting Air Traffic Controllers (ATCs) who maintain the safe and orderly movement of aircraft along major air routes around airports by giving pilots instructions for the height, speed, etc., of their aircraft. Organisations usually face different problems in selecting new personnel, estimating turnovers, and determining their personnel needs. Kaynak [2] stated that the basic function of personnel selection operations is to determine which candidates to appoint from among those who have applied for a specific job in the company. The air traffic control system must be error-free, because a single mistake can cost lives. Employee selection is therefore a crucial process and one of the main concerns of human resource management.

Certain selection criteria are the basis of assessment and evaluation for an air traffic control system. Communication skills, mathematical skills, awareness, personal skills, and motivation are the main criteria for selecting potential employees. A set of sub-criteria, which are as important as the main criteria, include oral communication, active listening, translating information, interpreting information, long-term memory, prioritisation, reasoning, sustained attention, working co-operatively, self-confidence, self-awareness, concentration, composure, and mathematical reasoning. An applicant should satisfy the maximum standards with respect to all these criteria. Dereli et al. [3] state that because it is not always possible for an organisation to recruit all the applicants, the organisation has to select between the applicants and employ the best one.

Karsak [4] modelled the personnel selection process using fuzzy multiple criteria programming together with fuzzy membership functions (MFs). Gatewood and Feild [5] defined employee selection as a process of collecting and evaluating information about an individual in order to extend an offer of employment. In this study, a type of fuzzy aggregation approach with a fuzzy decision tree was used for decision-making. A fuzzy decision tree uses aggregation operators on fuzzy sets to obtain different types of decision functions that best reflect the goals of the decision problem [6]. Three types of aggregation are most commonly used in fuzzy decision-making: 1) conjunctive aggregation of criteria; 2) disjunctive aggregation of criteria; and 3) compensatory aggregation of criteria. Chen et al. [7] stated that the fuzzy Technique for Order Preference by Similarity to Ideal Solution (TOPSIS) approach has various different applications in the literature, although it is not nearly as widely applied as other multi-criteria decision-making (MCDM) methods [8].

The TOPSIS method is an MCDM approach that is widely used in the literature [9]. With this method, the positive ideal solution maximises the benefit criteria of attributes and minimises the cost criteria of attributes, whereas the negative ideal solution maximises the cost criteria of attributes and minimises the benefit criteria of attributes. On the other hand, data-envelopment analysis (DEA) is a multi-criteria performance evaluation model that assesses the relative efficiency of each decision criterion within a set of decisionmaking units. This model calculates the attributes' efficiency using a mathematical model called DEA [10].

The paper is organised into four sections. Section 1 is the introduction, and Section 2 reviews the relevant literature. Section 3 presents the selection of ATCs by fuzzy sets and system and introduces and discusses the linguistic weights representing the importance of the criteria. Next, the fuzzy TOPSIS methodology for the qualitative evaluation of ATCs is presented, followed by the DEA. Sections 3.2 and 3.3 present the results of the research and the outcomes of the applied methodologies. The conclusions are given in Section 4. 


\section{LITERATURE REVIEW}

In traditional MCDM methods, including classic TOPSIS, the ratings and the weights of the criteria are known precisely. Many MCDM methods have been defined in the literature [11]. Under many conditions, however, deterministic data are inadequate to model real-life problems, since human judgments and preferences are often vague, imprecise, and difficult to estimate with exact numerical values. In this case, the fuzzy linguistic assessments approach is more realistic. This means the ratings and weights of the criteria in a real-life problem can be assessed by means of fuzzy linguistic variables instead of deterministic numerical values.

Huang et al. [12] stated that fuzzy set theory helps to measure the ambiguity of concepts that are associated with human beings' subjective judgment. Moreover, since evaluation follows from different decision-makers' views of linguistic variables in group decisionmaking situations, its evaluation must be conducted in an uncertain, fuzzy environment. The fuzzy decision tree approach has commonly been used to determine the criteria weights. It is one of the popular inductive learning methods that include two techniques: fuzzy logic and decision tree. In a fuzzy decision tree, each path from the root node to a terminal node corresponds to a fuzzy rule and a partitioned fuzzy subspace in the whole pattern space. This enhances the representative power of decision trees naturally with the knowledge component inherent in fuzzy logic, leading to better robustness and applicability in imprecise contexts [13]. Fuzzy decision trees assume that all domain attributes or linguistic variables have predefined fuzzy terms, determined in a data-driven manner using fuzzy restrictions.

In the study of Tsaur et al. [14], they transformed a fuzzy MCDM problem into an exact one via a centroid defuzzification approach and then solved the non-fuzzy MCDM problem using the TOPSIS method [15]. Chen [16] extended the TOPSIS method to fuzzy group decisionmaking situations by defining an exact Euclidean distance between any two fuzzy numbers. The literature review clearly showed that all the methods lead to an exact relative closeness for each alternative [9]. J iang et al. [17] stated that TOPSIS was widely used due to its logicality, rationality, and computational simplicity. The TOPSIS method has various successful applications in the literature: aggregate production planning [18], inter-company comparison [19], supplier evaluation and selection, risk assessment, and facility location selection [8], operating system selection [20], software selection [21], weapon selection [22], and performance measurement and evaluation [23]. Deng et al. [19] used the TOPSIS approach to compare company performances and financial ratio performance within a specific industry.

Salgado [24] studied several personality factors, including emotional stability, openness, agreeableness, extraversion, and conscientiousness. Ma and Li [25] studied the preferences between alternatives by fuzzy systems. Jessop [26] determined seven criteria from an overview of a job description: written communication, oral communication, planning, organising ability, team player, decisiveness, and working independently. Griffeth et al. [27] identified the causes of turnovers in a company by examining the sources of employee turnover. Singh and Mohanty [28] studied employee turnover and its cost. Zhu and Dowling [29] argued that organisations focused on potential employees' 'hard' practical skills and also their 'soft' behavioural skills. Zeydan et al. [30] stated that there were no studies in the literature that adopted a combined fuzzy TOPSIS and DEA approach before their application was published.

DEA applications are beneficial for many fields such as healthcare [31], education [32], banking [33], manufacturing enterprises [34], energy use [35], project evaluation and selection [35, 36], supplier selection [37], and personnel evaluation and selection [38, 39]. Furthermore, DEA has recently been given significant attention due to its ability to integrate other tools and techniques in order to formulate hybrid models that enhance the decision-making process. For example, DEA has been used to enrich the application of managerial models such as Quality Function Deployment [40] and Balanced Scorecard [41]. 
More recent literature has also shown that decision outcomes can be strengthened by merging the application of DEA with other quantitative approaches such as Artificial Neural Networks [39], the Knapsack problem [36], Analytical Hierarchy Process [34], Analytic Network Process [38], TOPSIS [42, 43], and fuzzy logic [34, 36].

\section{SELECTION OF AIR TRAFFIC CONTROLLERS BY FUZZY SETS}

As stated earlier, there are three different types of aggregation approaches [6] for decision-making. In the event that the decision-maker seeks compensatory decision behaviour, there are boundary conditions on the decision, rather than the personal preferences of the decision-maker, that determine the choice of the decision function. The ATC problem was formulated as the fulfilment of five criteria. Figure 1 depicts a set of criteria $C=\left\{C_{1}, \ldots, C_{5}\right\}$ for selecting the best applicant in civil aviation. For instance, $C_{2}$ stands for 'mathematical skills' of applicants and includes six sub-criteria (parameters) $\mathrm{C}_{2}=\left\{\mathrm{C}_{1}, \ldots, \mathrm{C}_{6}\right\}$ which are 'numerical ability', 'translating information', 'interpreting information', 'mathematical reasoning', 'confirmation capability', and 'information processing'. Since all of these criteria are important for the selection of ATCs, all of them must be met by the assessed candidates.

The goals, however, cannot be combined in a compensatory manner, since an increase in the interpreting information cannot be compensated to some degree by an increase in the speed of the response and confirmation capability, and vice versa. In order to model the different types of decision behaviour, the decision-maker needs to establish a hierarchy of decision functions. The constraints were combined by a conjunctive aggregation technique for modelling the simultaneous satisfaction, and the goals were combined by using a weighting operator (W). The aggregated results were then combined in a higher-level tnorm. Figure 1 depicts the hierarchical structure of criteria for an ATC candidate.

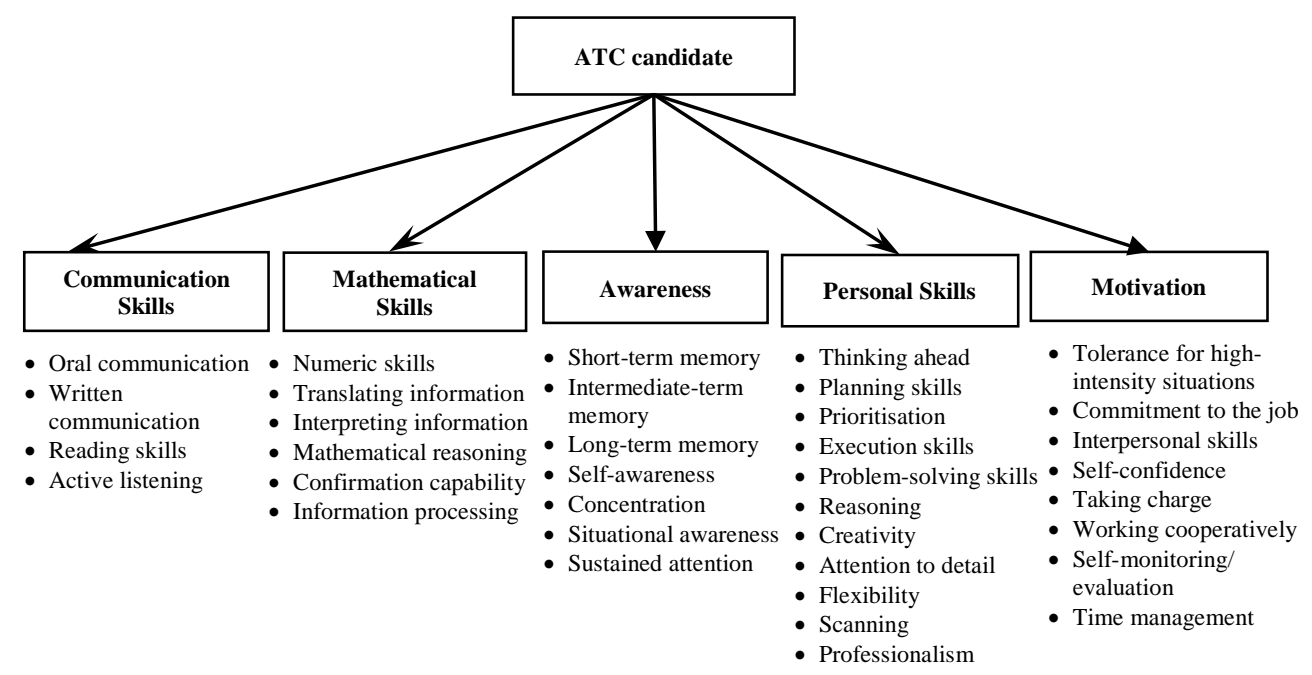

Figure 1: The criteria and sub-criteria of an ATC candidate

The aim of this study is to propose a method to determine the most eligible candidates for an ATC system. In order to determine the best applicant $\left(A_{i}\right)$, the main criteria $\left(C_{i}\right)$ were divided into five elements. Hence, $C_{1}$ stands for 'communication skills', $C_{2}$ stands for 'mathematical skills', $C_{3}$ stands for 'awareness', $C_{4}$ stands for 'personal skills', and $C_{5}$ stands for 'motivation'. These main criteria include many sub-criteria that are also very important for selecting controllers. Measuring the degree to which criteria are met, the MFs fulfil a role similar to the utility functions that was obtained from an alternative decision criterion. The fuzzy sets approach uses operators from the fuzzy set theory to aggregate the decisions so that more flexible aggregation behaviour can be modelled [6]. The weight 
factors of criteria can be normalised depending on the requirements of the decision problem. In this study, the sub-criteria set was assessed and normalised by the fuzzy decision tree approach. As depicted in Figure 2, the decision tree of $\mathrm{C}_{1}$ (communication skills), was defined by the set of weights $\left\{w_{11}, w_{12}, w_{13}\right.$, and $\left.w_{14}\right\}$. These sub-criteria stand for the weights of 'oral communication', 'written communication', 'reading skills', and 'active listening', respectively. C3 stands for the awareness of controllers, which includes their 'short-term, intermediate-term and long-term memory', 'self-awareness', 'concentration', 'situational awareness', and 'sustained attention'.
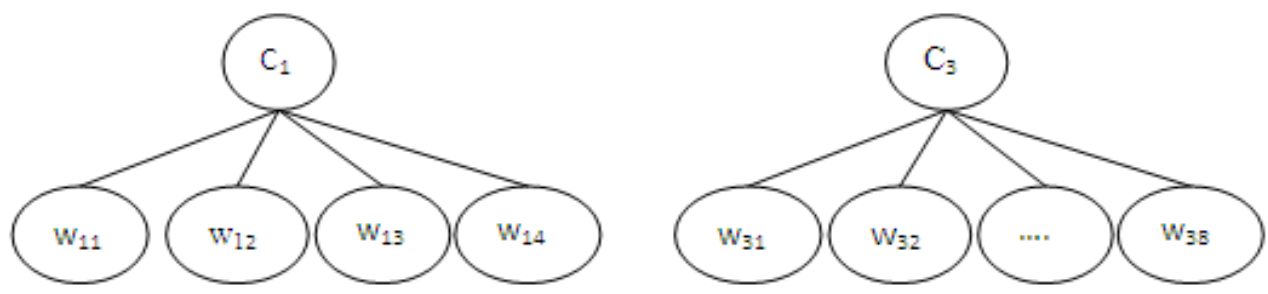

Figure 2: A fuzzy decision tree for the combination of sub-criteria by different operators

Table 1 shows the linguistic weights that represent the importance of the criteria. The decision-makers (DMs) are a team of national and international members selected to evaluate the performance of applicants. The evaluation of sub-criteria weights was carried out by fuzzy linguistic terms. These terms and their triangular fuzzy numbers are presented in Table 1.

Table 1: Fuzzy linguistic terms for the weight of criteria

\begin{tabular}{|l|l|}
\hline Fuzzy term sets & Fuzzy triangular numbers \\
\hline Very low (VL) & $(0,0,0.1)$ \\
\hline Low (L) & $(0,0.1,0.3)$ \\
\hline Fair (F) & $(0.1,0.3,0.5)$ \\
\hline Average (A) & $(0.3,0.5,0.7)$ \\
\hline Average High (AH) & $(0.5,0.7,0.9)$ \\
\hline High (H) & $(0.7,0.9,1)$ \\
\hline Very high (VH) & $(0.9,1,1)$ \\
\hline
\end{tabular}

MCDM is concerned with the selection of a decision alternative out of a finite and quantifiable set of alternatives that are important for the decision. Fuzzy multi-attribute decision theory applies fuzzy set theory to solve the discrete choice problem. Table 2 presents the weights of the sub-criteria 'communication skills', as determined by the different DMs. The weights allocated to these sub-criteria were fuzzy weights, and the evaluation approach was carried out by fuzzy linguistic terms. For instance, 'oral communication' was assessed by five DMs, and the fuzzy decision set of this sub-criterion consists of the elements such as \{Very high (VH), Very high $(\mathrm{VH})$, High $(\mathrm{H})$, Very high $(\mathrm{VH})$, and Very high $(\mathrm{VH})\}$.

Table 2: Decision matrix of communication skills by fuzzy linguistic terms

\begin{tabular}{|l|l|l|l|l|l|}
\hline $\begin{array}{l}\mathbf{C}_{1} \\
\text { Communication skills }\end{array}$ & $\mathbf{D M}_{\mathbf{1}}$ & $\mathbf{D M}_{\mathbf{2}}$ & $\mathbf{D M}_{\mathbf{3}}$ & $\mathbf{D M}_{\mathbf{4}}$ & $\mathbf{D M}_{\mathbf{5}}$ \\
\hline $\begin{array}{l}\mathbf{C}_{11}: \\
\text { Oral communication }\end{array}$ & $\mathrm{VH}$ & $\mathrm{VH}$ & $\mathrm{H}$ & $\mathrm{VH}$ & $\mathrm{VH}$ \\
\hline $\begin{array}{l}\mathbf{C}_{12}: \\
\text { Written communication }\end{array}$ & $\mathrm{H}$ & $\mathrm{H}$ & $\mathrm{A}$ & $\mathrm{A}$ & $\mathrm{VH}$ \\
\hline $\begin{array}{l}\mathbf{C}_{13}: \\
\text { Reading capability }\end{array}$ & $\mathrm{H}$ & $\mathrm{A}$ & $\mathrm{A}$ & $\mathrm{H}$ & $\mathrm{H}$ \\
\hline $\begin{array}{l}\mathbf{C}_{14}: \\
\text { Active listening }\end{array}$ & $\mathrm{VH}$ & $\mathrm{VH}$ & $\mathrm{H}$ & $\mathrm{H}$ & $\mathrm{H}$ \\
\hline
\end{tabular}


The weights of the sub-criteria were aggregated by Equation 1 with $\mathrm{N}=5$ DMs. The results are presented in Table 3. In this respect, the fuzzy terms and the weights presented in Table 1 were employed for further processing of the weights. The weight of the criterion 'communication skills' is presented in Table 3. The weights of the other criteria and subcriteria were determined in a similar way.

$$
\begin{aligned}
\tilde{w}_{i j} & =\frac{1}{N}\left\{\tilde{w}_{i j}^{(1)}+\tilde{w}_{i j}^{(2)}+\ldots+\tilde{w}_{i j}^{(N)}\right\} \\
& w_{11}=\frac{(0.9,1,1)+(0.9,1,1)+(0.7,0.9,1)+(0.9,1,1)+(0.9,1,1)}{5}=(0.86,0.98,1)
\end{aligned}
$$

\begin{tabular}{|c|c|c|c|c|c|c|}
\hline $\begin{array}{l}\mathrm{C}_{1} \\
\text { Communication } \\
\text { skills }\end{array}$ & $\mathrm{DM}_{1}$ & $\mathrm{DM}_{2}$ & $\mathrm{DM}_{3}$ & $\mathrm{DM}_{4}$ & $\mathrm{DM}_{5}$ & $\begin{array}{c}\text { Weight of sub- } \\
\text { criteria aggregation }\end{array}$ \\
\hline $\begin{array}{l}\mathrm{C}_{11}: \\
\text { Oral } \\
\text { communication }\end{array}$ & $\begin{array}{l}(0.9,1 \\
1)\end{array}$ & $\begin{array}{l}(0.9,1 \\
1)\end{array}$ & $\begin{array}{l}(0.7 \\
0.9,1)\end{array}$ & $\begin{array}{l}(0.9,1, \\
1)\end{array}$ & $\begin{array}{l}(0.9,1 \\
1)\end{array}$ & $(0.86,0.98,1)$ \\
\hline $\begin{array}{l}\mathrm{c}_{12}: \\
\text { Written } \\
\text { communication }\end{array}$ & $\begin{array}{l}(0.7 \\
0.9,1)\end{array}$ & $\begin{array}{l}(0.7 \\
0.9,1)\end{array}$ & $\begin{array}{l}(0.3 \\
0.5,0.7)\end{array}$ & $\begin{array}{l}(0.3, \\
0.5,0.7)\end{array}$ & $\begin{array}{l}(0.9,1 \\
1)\end{array}$ & $(0,58,0.76,0.88)$ \\
\hline $\begin{array}{l}\mathrm{C}_{13}: \\
\text { Reading capability }\end{array}$ & $\begin{array}{l}0.7 \\
0.9,1)\end{array}$ & $\begin{array}{l}0.3 \\
0.5,0.7)\end{array}$ & $\begin{array}{l}(0.3, \\
0.5,0.7) \\
\end{array}$ & $\begin{array}{l}0.7 \\
0.9,1) \\
\end{array}$ & $\begin{array}{l}0.7 \\
0.9,1)\end{array}$ & $(0.54,0.74,0.88)$ \\
\hline $\begin{array}{l}\mathrm{C}_{14}: \\
\text { Active listening }\end{array}$ & $\begin{array}{l}(0.9,1 \\
1)\end{array}$ & $\begin{array}{l}(0.9,1 \\
1)\end{array}$ & $\begin{array}{l}(0.7, \\
0.9,1)\end{array}$ & $\begin{array}{l}(0.7 \\
0.9,1)\end{array}$ & $\begin{array}{l}(0.7, \\
0.9,1)\end{array}$ & $(0.78,0.76,1)$ \\
\hline
\end{tabular}

Table 3: The weights of communication skills

Because of the compensation, the output of averaging operators is always between the minimum and the maximum sets [6]. The median is a particular type of averaging operator. Hence, given $n$ different numbers of weights $\left(w_{i n}\right)$ with $w_{11} \leq \ldots \leq w_{i n}$, their median is defined by Equation 2.

$$
\operatorname{med}\left(w_{11}, \ldots, w_{1 n}\right)= \begin{cases}w_{\frac{n+1}{2}} & \text { if nis odd } \\ \frac{1}{2}\left(w_{\frac{n}{2}}+w_{\frac{n}{2}+1}\right) & \text { if nis even }\end{cases}
$$

The weight of 'communication skills' was found to be $C_{1}=(0.66,0.76,0.94)$. The weights of the other main criteria were calculated in the same way and are presented in Table 4. Hence, the importance of decision criteria have been modelled by weighting factors $w_{j}>0$, $\mathrm{j}=1, \ldots, \mathrm{n}$ which is a number indicating the relative importance that a decision-maker assigns to a criterion in relation to other decision criteria. The larger the weight factor, the more important the corresponding criterion assumed for the outcome of the decision problem. The weight factors are usually assumed to be elements of the unit interval, e.g., $w_{j} \varepsilon[0,1], j=1, \ldots, n$.

Table 4: Fuzzy weights of main criteria

\begin{tabular}{|l|c|}
\hline Main criteria & Fuzzy attribute weights \\
\hline Communication skills & $(0.66,0.76,0.94)$ \\
\hline Mathematical skills & $(0.74,0.82,0.91)$ \\
\hline Awareness & $(0.58,0.64,0.76)$ \\
\hline Personal skills & $(0.63,0.71,0.85)$ \\
\hline Motivation & $(0.72,0.81,0.92)$ \\
\hline
\end{tabular}

\subsection{Fuzzy TOPSIS methodology for multiple criteria decision-making}

TOPSIS is one of many techniques used when dealing with MCDM problems. It simultaneously considers the shortest distance from the positive ideal solution (PIS) and the farthest distance from the negative ideal solution (NIS). The preference order is ranked according to their relative closeness when combining two distance measures [17]. TOPSIS is an attractive 
method because only limited subjective input is needed from the DMs. For the employee selection problem, the criteria are not equally important and the input data or related information is not known precisely. After the main criteria weights were determined, the rating of each ATC was performed. Table 5 presents the importance of attributes and the rating of alternatives with respect to each criterion.

Table 5: Fuzzy terms and criteria rating

\begin{tabular}{|c|c|}
\hline Fuzzy Language & Fuzzy Number \\
\hline Poor (P) & $(1,2,3)$ \\
\hline Fair (F) & $(1,2.5,4)$ \\
\hline Good (G) & $(2.5,4,5.5)$ \\
\hline Very Good (VG) & $(4,5.5,7)$ \\
\hline Excellent (E) & $(5.5,7,9)$ \\
\hline
\end{tabular}

In general, the fuzzy TOPSIS procedure is applied using the following steps [16]:

Step 1: The importance weight of the decision criteria and the ratings: Table 4 presents the weights of the decision criteria that were calculated. Two different approaches were used to calculate the weights. As the decision-maker wants to satisfy all the main decision criteria simultaneously, the fuzzy operators were employed for the aggregation. The weights of sub-criteria decision aggregation were presented by a fuzzy decision tree; hence, Equation 1 was employed to average the sub-criteria assignments. Let $A=\left\{A_{1}\right.$, $A_{2}, \ldots, A_{10}$ \} be the set of applicants for the ATCs positions, for the ten candidates who were considered. Fuzzy linguistic terms constituted the basis of the grading approach. The DMs used the linguistic rating to evaluate the alternatives with respect to each sub-criterion. The importance degree of each objective was incorporated into the formulation using fuzzy priorities and rating of alternatives. The priority weight of each alternative (applicant) was obtained by multiplying the matrix of evaluation ratings by the vector of criteria weights, and summing overall attributes. The information about the alternatives needs to be combined in order to determine the overall suitability of the applicant. This is done by an aggregation function. This function in fuzzy decision-making is called the decision function [6].

Table 6 depicts the fuzzy decisions made for the 'communication skills' criteria of applicant \#1. Equation 3 was employed to combine the decisions and calculate the average decision for each sub-criterion for $n=5$ DMs. The average decision for all sub-criteria was calculated in the same way, and is presented in Table 7.

Table 6: Fuzzy decision matrix for applicant \#1

\begin{tabular}{|l|c|c|c|c|c|}
\hline $\begin{array}{l}\mathbf{A}_{\mathbf{1}} \text { : } \\
\text { (Applicant \#1) }\end{array}$ & $\mathbf{D M}_{\mathbf{1}}$ & $\mathbf{D M}_{\mathbf{2}}$ & $\mathbf{D M}_{\mathbf{3}}$ & $\mathbf{D M}_{\mathbf{4}}$ & $\mathbf{D M}_{\mathbf{5}}$ \\
\hline $\begin{array}{l}\mathrm{X}_{11}: \\
\text { Oral communication }\end{array}$ & $\mathrm{P}$ & $\mathrm{F}$ & $\mathrm{G}$ & $\mathrm{G}$ & $\mathrm{F}$ \\
\hline $\begin{array}{l}\mathrm{X}_{12}: \\
\text { Written communication }\end{array}$ & $\mathrm{G}$ & $\mathrm{G}$ & VG & F & G \\
\hline $\begin{array}{l}\mathrm{X}_{13}: \\
\text { Reading skills }\end{array}$ & VG & VG & VG & G & VG \\
\hline $\begin{array}{l}\mathrm{X}_{14}: \\
\text { Active listening }\end{array}$ & $\mathrm{E}$ & $\mathrm{G}$ & VG & VG & VG \\
\hline
\end{tabular}

$$
\tilde{x}_{i j}=\frac{1}{N}\left\{\tilde{x}_{i j}^{(1)}+\tilde{x}_{i j}^{(2)}+\ldots+\tilde{x}_{i j}^{(N)}\right\}
$$

where $\tilde{X}_{i j}$ is the rating decision of the k-th decision-maker for an applicant with respect to the sub-criterion $(+)$ indicates the fuzzy arithmetic summation function. Let $X=\left(\tilde{X}_{i j}\right)_{n \times m}$ be a fuzzy decision matrix characterised by MFs $\mu_{x i j}(x)(i=1, \ldots, n, j=1, \ldots, m)$ if the criteria are 
assessed using the same set as fuzzy linguistic variables, then the fuzzy decision matrix $X$ is the same dimension and needs to be normalised.

If $\tilde{x}_{i j}=\left(a_{i j}, b_{i j}, c_{i j}\right) \quad(i=1, \ldots, n, j=1, . ., m)$ are triangular fuzzy numbers, then the normalisation process can be conducted. In a fuzzy MCDM problem, criteria values are usually characterised by fuzzy numbers. A fuzzy number is a convex fuzzy set, characterised by a given interval of real numbers, each with a grade of membership between 0 and 1 . The most commonly used fuzzy numbers are triangular fuzzy numbers, whose MFs are defined by Equation 4.

$$
\mu_{x_{i j}}(x)= \begin{cases}(x-a) /(b-a), & a \leq x \leq b \\ (c-x) /(c-b), & b \leq x \leq c \\ 0, & \text { otherwise }\end{cases}
$$

If $\tilde{x}_{i j}=\left(a_{i j}, b_{i j}, c_{i j}\right) \quad(i=1, \ldots, n, j=1, . ., m)$ are triangular fuzzy numbers, then the normalisation process is conducted by Equation 6 . Triangular fuzzy numbers are usually denoted as $(a, b, c)$. According to Zadeh's extension principle, a fuzzy number/ set A (set of applicants) can be expressed by its intervals.

Step 2: It is possible to obtain the normalised fuzzy decision matrix denoted by $\widetilde{R}_{i j}$ :

Let $\widetilde{\boldsymbol{R}}_{i j}$ present the fuzzy membership degree of applicants with regard to the main criteria, and let $B$ and $C$ present the set of benefit criteria and set of cost criteria respectively, then:

$$
\begin{aligned}
& \tilde{R}_{i j}=\left[\tilde{r}_{i j}\right]_{m \times n} \\
& \tilde{r}_{i j}=\left(\frac{a_{i j}}{c_{j}^{*}}, \frac{b_{i j}}{c_{j}^{*}}, \frac{c_{i j}}{c_{j}^{*}}\right), \quad j \in B . \\
& c_{j}^{*}=\max _{i} c_{i j}, \quad \text { if } \quad j \in B ; \\
& \tilde{r}_{i j}=\left(\frac{a_{j}^{-}}{c_{i j}}, \frac{a_{j}^{-}}{b_{i j}}, \frac{a_{j}^{-}}{a_{i j}}\right), \quad j \in C . \\
& a_{j}^{-}=\min _{i} a_{i j}, \quad \text { if } j \in C .
\end{aligned}
$$

Step 3: The weighted normalised fuzzy decision matrix is constructed using Equation 8: the normalisation method made the result commensurable in the range of triangular fuzzy numbers, in the interval of $[0,1]$.

$$
\begin{aligned}
& \tilde{V}=\left[\tilde{v}_{i j}\right]_{m \times n}, \quad i=1,2, \ldots, \mathrm{m} ; \mathrm{j}=1,2, \ldots, \mathrm{n} \\
& \tilde{V}_{i j}=\tilde{r}_{i j}(.) \tilde{w}_{j}
\end{aligned}
$$

\subsection{Fuzzy application procedure of fuzzy TOPSIS methodology for the selection of ATCS}

The objective of this study is to determine the most eligible candidates for an air traffic control system. The controller selection problem is usually very complex: many vague criteria have to be considered, and the selection system must be error-free and reliable. The main criteria and sub-criteria of the air traffic control system selected for this study were presented in Figure 1. The MCDM approach is pertinent to making a decision among a 
finite and quantifiable set of alternatives. The selection system provides information regarding the complete set of criteria that are assessed. Similarly, fuzzy multi-attribute decision theory applies fuzzy set theory to solve discrete, vague, and ill-defined real-life problems.

With this in mind, the fuzzy weights were determined for all criteria and sub-criteria, and the evaluation approach was carried out by employing fuzzy linguistic terms. In this respect, the fuzzy terms and the weights presented in Table 1 were employed for further processing of the weights. The weights of the sub-criteria were aggregated by Equation 1; the results are presented in Table 3. The median approach was employed for averaging the operators. Hence, for given $n$ different numbers of weights $\left(w_{i n}\right)$ for each sub-criterion, the median of sub-criteria were determined by Equation 2. The weights of all the main criteria were then calculated (Table 4). Fuzzy TOPSIS is an attractive method for employee selection problems where the criteria are not equally important and the input data or related information is not known precisely. After the main criteria weights were determined, the rating of ATCS was carried out. Table 5 presents the importance of attributes and the rating of alternatives with respect to each criterion. The rating of the main criteria and sub-criteria was identified by $X$ and $\tilde{x}_{i j}$ respectively in this study. The rating decision of the $\mathrm{k}$-th decision-maker for an applicant with respect to the sub-criteria $(+)$ indicates the fuzzy arithmetic summation function. Hence, Table 7 presents the fuzzy triangular grading of 'oral communication skills' for applicant \#1. This table also shows the average decision for applicant \#1 made by five DMs. Equation 3 was employed for the calculation of average grades. A sample calculation of averaging the decision for applicant \# 1 with regard to 'communication skills' is presented below.

$$
x_{11}=\frac{(1,2,3)+(1,2.5,4)+(2.5,4,5.5)+(2.5,4,5.5)+(1.2 .5,4)}{5}=(1.6,3,4.4)
$$

Table 7: Fuzzy triangular numbers for grading the applicants with respect to criteria

\begin{tabular}{|c|c|c|c|c|c|c|}
\hline $\begin{array}{l}\text { A }_{1}: \\
\text { Applicant \#1 }\end{array}$ & $\mathrm{DM}_{1}$ & $\mathrm{DM}_{2}$ & $\mathrm{DM}_{3}$ & $\mathrm{DM}_{4}$ & $\mathrm{DM}_{5}$ & $\begin{array}{l}\text { Averag } \\
\text { e of } \\
\text { decisio } \\
n\end{array}$ \\
\hline $\begin{array}{l}\mathbf{X}_{11}: \\
\text { Oral communication }\end{array}$ & $(1,2,3)$ & $(1,2.5,4)$ & $\begin{array}{ll}(2.5, & 4, \\
5.5) & \end{array}$ & $\begin{array}{l}(2.5, \quad 4, \\
5.5)\end{array}$ & $(1,2.5,4)$ & $\begin{array}{l}(1.6,3, \\
4.4)\end{array}$ \\
\hline $\begin{array}{l}\mathbf{X}_{12}: \\
\text { Written } \\
\text { communication }\end{array}$ & $\begin{array}{l}(2.5, \quad 4, \\
5.5)\end{array}$ & $\begin{array}{l}(2.5, \quad 4, \\
5.5)\end{array}$ & $(4,5.5,7)$ & $(1,2.5,4)$ & $\begin{array}{l}(2.5, \quad 4, \\
5.5)\end{array}$ & $\begin{array}{l}(2.5 \\
4.1 \\
5.5)\end{array}$ \\
\hline $\begin{array}{l}\mathbf{X}_{13}: \\
\text { Reading skills }\end{array}$ & $(4,5.5,7)$ & $(4,5.5,7)$ & $(4,5.5,7)$ & $\begin{array}{l}(2.5, \quad 4, \\
5.5)\end{array}$ & $(4,5.5,7)$ & $\begin{array}{l}(3.7 \\
5.2 \\
6.7)\end{array}$ \\
\hline $\begin{array}{l}\mathrm{X}_{14}: \\
\text { Active listening }\end{array}$ & $(5.5,7,9)$ & $\begin{array}{ll}(2.5, & 4, \\
5.5) & \end{array}$ & $(4,5.5,7)$ & $(4,5.5,7)$ & $(4,5.5,7)$ & $\begin{array}{l}(4,5.5, \\
7.1)\end{array}$ \\
\hline
\end{tabular}

The grades of the other applicants with respect to the main criteria were calculated in the same way (Table 8). The fuzzy MCDM problem can be illustrated in matrix form. as given in Equation 9.

$$
\tilde{D}=\left[\begin{array}{cccc}
\tilde{x}_{11} & \tilde{x}_{12} & \ldots & \tilde{x}_{1 n} \\
\tilde{x}_{21} & \tilde{x}_{22} & \ldots & \tilde{x}_{2 n} \\
\vdots & \vdots & \ldots & \vdots \\
\tilde{x}_{m 1} & \tilde{x}_{m 2} & \ldots & \tilde{x}_{m n}
\end{array}\right]
$$

The fuzzy numbers with respect to ten applicants, for the construction of the fuzzy decision matrix, are presented in Table 8. For instance, decision-maker \#1 $\left(D_{1}\right)$ assessed and graded applicant \#3 with $(4.5,5.6,6.6)$ and applicant \#9 with $(2.5,3.3,4.1)$, in respect of 
criterion \#1. Similarly, decision-maker \#1 assessed and graded the same applicants with $(5.9,6.9,7.8)$ and $(3.5,4.5,5.5)$ for criterion $\# 5$.

The fuzzy TOPSIS approach was employed to transform the exact outcomes of all criteria values to fuzzy membership values. So different criteria of the air traffic control system were made commensurable by transforming them to fuzzy membership scales. In this sense, the importance of criteria became a well-defined concept in terms of the sensitivity of the aggregation to an individual membership value. For instance, as it appears in Table 8, the row corresponding to $A_{i} S, C_{j}^{*}$ (see Equation 7) has been calculated for each applicant: 7.5 for the first applicant $\left(A_{1}\right), 8.5$ for the second applicant, 8.4 for the third applicant, 8.2 for the fourth applicant, 7.4 for the fifth applicant, 8.4 for sixth applicant, 8.3 for the seventh applicant, 7.1 for the eighth applicant, 5.5 for the ninth applicant, and 8.8 for the tenth applicant. Some sample calculations of $\mathrm{c}_{\mathrm{j}}{ }^{*}$ are presented below.

$c_{1}^{*}=\max [(3.1,4.6,6.1),(5.8,6.7,7.5),(3.5,5,6.5),(5.2,6.3,7.3),(3.4,5.1,6.8)]=7.5$

$c_{6}^{*}=\max [(6.9,7.7,8.4),(5.5,6.5,7.5),(6.2,7.3,8.4),(4.5,5.5,6.5),(5.9,6.6,7.2)]=8.4$

$c_{10}^{*}=\max [(7.1,7.9,8.8),(6.3,7.2,8.1),(5.5,6.3,7.0),(4.8,5.6,6.4),(5.8,6.7,7.5)]=8.8$

Table 8: Fuzzy decision matrix of grades determined for each applicant

\begin{tabular}{|c|c|c|c|c|c|}
\hline \multicolumn{7}{|c|}{ Criteria } \\
\hline Applicants & $\mathbf{C}_{\mathbf{1}}$ & \multicolumn{1}{|c|}{$\mathbf{C}_{\mathbf{2}}$} & $\mathbf{C}_{\mathbf{3}}$ & $\mathbf{C}_{\mathbf{4}}$ & $\mathbf{C}_{\mathbf{5}}$ \\
\hline $\mathbf{A}_{\mathbf{1}}$ & $(3.1,4.6,6.1)$ & $(5.8,6.7,7.5)$ & $(3.5,5,6.5)$ & $(5.2,6.3,7.3)$ & $(3.4,5.1,6.8)$ \\
\hline $\mathbf{A}_{\mathbf{2}}$ & $(3.7,5.3,6.9)$ & $(6.1,7.1,8.2)$ & $(5.3,6.4,7.5)$ & $(6.4,7.5,8.5)$ & $(5.8,6.9,7.9)$ \\
\hline $\mathbf{A}_{\mathbf{3}}$ & $(4.5,5.6,6.6)$ & $(3.0,4.5,6.0)$ & $(5.4,6.4,7.5)$ & $(6.2,7.3,8.4)$ & $(5.9,6.9,7.8)$ \\
\hline $\mathbf{A}_{\mathbf{4}}$ & $(5.5,6.6,7.6)$ & $(6.1,7.1,8.1)$ & $(5.9,6.7,7.5)$ & $(5.8,6.7,7.6)$ & $(6.4,7.3,8.2)$ \\
\hline $\mathbf{A}_{\mathbf{5}}$ & $(5.2,6.3,7.4)$ & $(4.5,5.3,6)$ & $(4.8,5.5,6.2)$ & $(5.1,6.1,7)$ & $(5.0,6.0,7.0)$ \\
\hline $\mathbf{A}_{\mathbf{6}}$ & $(6.9,7.7,8.4)$ & $(5.5,6.5,7.5)$ & $(6.2,7.3,8.4)$ & $(4.5,5.5,6.5)$ & $(5.9,6.6,7.2)$ \\
\hline $\mathbf{A}_{\mathbf{7}}$ & $(6.4,7.4,8.3)$ & $(5.2,5.8,6.4)$ & $(4.5,5.2,5.8)$ & $(4.4,5.3,6.2)$ & $(4.1,5.1,6)$ \\
\hline $\mathbf{A}_{\mathbf{8}}$ & $(3.6,4.4,5.2)$ & $(4.1,5,5.9)$ & $(4.2,5.4,6.5)$ & $(5.5,6.3,7.1)$ & $(4.8,5.6,6.4)$ \\
\hline $\mathbf{A}_{\mathbf{9}}$ & $(2.5,3.3,4.1)$ & $(3.2,4.1,5.0)$ & $(1.8,2.7,3.5)$ & $(4.3,4.8,5.2)$ & $(3.5,4.5,5.5)$ \\
\hline $\mathbf{A}_{\mathbf{1 0}}$ & $(7.1,7.9,8.8)$ & $(6.3,7.2,8.1)$ & $(5.5,6.3,7.0)$ & $(4.8,5.6,6.4)$ & $(5.8,6.7,7.5)$ \\
\hline
\end{tabular}

The set of $\tilde{r}_{i j}$ is calculated by using Equation 6; the outcomes are presented in Table 9.

$$
\tilde{r}_{12}=\left(\frac{5.8}{7.5}, \frac{6.7}{7.5}, \frac{7.5}{7.5}\right)=(0.77,0.89,1.00) \quad \tilde{r}_{65}=\left(\frac{5.9}{8.4}, \frac{6.6}{8.4}, \frac{7.2}{8.4}\right)=(0.70,0.79,0.86)
$$

Equation 5 was employed for the determination of $\widetilde{R}_{i j}$; the results are presented in Table 9. $\widetilde{R}_{i j}$ presents the fuzzy membership degree of applicants with regard to the main criteria.

$$
\begin{gathered}
\widetilde{R}_{11}=[(0.41,0.61,0.81),(0.77,0.89,1.00),(0.47,0.67,0.87),(0.69,0.84,0.97),(0.45 \\
0.68,0.91)]
\end{gathered}
$$


Table 9: The fuzzy membership degrees of applicants for decision-making

\begin{tabular}{|c|c|c|c|c|c|}
\hline$\widetilde{R}_{i j}$ & $C_{1}$ & $C_{2}$ & $C_{3}$ & $C_{4}$ & $C_{5}$ \\
\hline$A_{1}$ & $\begin{array}{l}(0.41,0.61, \\
0.81)\end{array}$ & $\begin{array}{l}(0.77,0.89, \\
1.00)\end{array}$ & $\begin{array}{l}(0.47,0.67, \\
0.87)\end{array}$ & $\begin{array}{l}(0.69,0.84, \\
0.97)\end{array}$ & $\begin{array}{l}(0.45,0.68, \\
0.91)\end{array}$ \\
\hline$A_{2}$ & $\begin{array}{l}(0.44,0.62, \\
0.81)\end{array}$ & $\begin{array}{l}(0.72,0.84, \\
0.96)\end{array}$ & $\begin{array}{l}(0.62,0.75 \\
0.88)\end{array}$ & $\begin{array}{l}(0.75,0.88, \\
1.00)\end{array}$ & $\begin{array}{l}(0.68,0.81 \\
0.93)\end{array}$ \\
\hline$A_{3}$ & $\begin{array}{l}(0.54,0.68, \\
0.79)\end{array}$ & $\begin{array}{l}(0.36,0.54, \\
0.72)\end{array}$ & $\begin{array}{l}(0.64,0.76, \\
0.89)\end{array}$ & $\begin{array}{l}(0.74,0.87, \\
1.00)\end{array}$ & $\begin{array}{l}(0.70,0.82, \\
0.93)\end{array}$ \\
\hline $\mathbf{A}_{4}$ & $\begin{array}{l}(0.67,0.80 \\
0.93)\end{array}$ & $\begin{array}{l}(0.74,0.87, \\
0.99)\end{array}$ & $\begin{array}{l}(0.72,0.82, \\
0.91)\end{array}$ & $\begin{array}{l}(0.71,0.82, \\
0.93)\end{array}$ & $\begin{array}{l}(0.78,0.89, \\
1.00)\end{array}$ \\
\hline$A_{5}$ & $\begin{array}{l}(0.70,0.85 \\
1.00)\end{array}$ & $\begin{array}{l}(0.61,0.72, \\
0.81)\end{array}$ & $\begin{array}{l}(0.65,0.74 \\
0.84)\end{array}$ & $\begin{array}{l}(0.69,0.82 \\
0.95)\end{array}$ & $\begin{array}{l}(0.68,0.81 \\
0.95)\end{array}$ \\
\hline$A_{6}$ & $\begin{array}{l}(0.82,0.92, \\
1.00)\end{array}$ & $\begin{array}{l}(0.65,0.77, \\
0.89)\end{array}$ & $\begin{array}{l}(0.74,0.87, \\
1.00)\end{array}$ & $\begin{array}{l}(0.54,0.65, \\
0.77)\end{array}$ & $\begin{array}{l}(0.70,0.79, \\
0.86)\end{array}$ \\
\hline$A_{7}$ & $\begin{array}{l}(0.77,0.89, \\
1.00)\end{array}$ & $\begin{array}{l}(0.63,0.70, \\
0.77)\end{array}$ & $\begin{array}{l}(0.54,0.63, \\
0.70)\end{array}$ & $\begin{array}{l}(0.53,0.64, \\
0.75)\end{array}$ & $\begin{array}{l}(0.49,0.62 \\
0.72)\end{array}$ \\
\hline$A_{8}$ & $\begin{array}{l}(0.50,0.70 \\
0.73)\end{array}$ & $\begin{array}{l}(0.58,0.70, \\
0.83)\end{array}$ & $\begin{array}{l}(0.59,0.76 \\
0.92)\end{array}$ & $\begin{array}{l}(0.77,0.89, \\
1.00)\end{array}$ & $\begin{array}{l}(0.68,0.79, \\
0.90)\end{array}$ \\
\hline$A_{9}$ & $\begin{array}{l}(0.45,0.60 \\
0.75)\end{array}$ & $\begin{array}{l}(0.58,0.75, \\
0.91)\end{array}$ & $\begin{array}{l}(0.33,0.49 \\
0.64)\end{array}$ & $\begin{array}{l}(0.78,0.87, \\
0.95)\end{array}$ & $\begin{array}{l}(0.64,0.81 \text {, } \\
1.00)\end{array}$ \\
\hline$A_{10}$ & $\begin{array}{l}(0.81,0.90, \\
1.00)\end{array}$ & $\begin{array}{l}(0.72,0.82, \\
0.92)\end{array}$ & $\begin{array}{l}(0.63,0.72, \\
0.80)\end{array}$ & $\begin{array}{l}(0.55,0.64, \\
0.73)\end{array}$ & $\begin{array}{l}(0.66,0.76, \\
0.85)\end{array}$ \\
\hline $\begin{array}{c}\text { Weight of } \\
\text { criteria }\end{array}$ & $\begin{array}{l}(0.66,0.76, \\
0.94)\end{array}$ & $\begin{array}{l}(0.74,0.82, \\
0.91)\end{array}$ & $\begin{array}{l}(0.58,0.64, \\
0.76)\end{array}$ & $\begin{array}{l}(0.63,0.71, \\
0.85)\end{array}$ & $\begin{array}{l}(0.72,0.81 \\
0.92)\end{array}$ \\
\hline
\end{tabular}

The normalised decision matrix denoted by $\widetilde{R}_{i j}$ was obtained by the application of Equation 6 and Equation 7. Equation 8 was employed to calculate the normalised fuzzy decision matrix. To avoid the complication of normalisation, the linear scale transformation was used for the various criteria scales to convert into the fuzzy weighted membership degree. Some example calculations are as follows:

$$
\begin{aligned}
& V_{12}=(0.77,0.89,1.00)(.)(0.74,0.82,0.92)=(0.57,0.73,0.91) \\
& V_{41}=(0.67,0.80,0.93)(.)(0.66,0.76,0.94)=(0.44,0.61,0.87)
\end{aligned}
$$

For instance, $V_{12}=(0.57,0.73,0.91)$ is a fuzzy triangular grading decision allocated to applicant \#1 for 'mathematical skills'. Similarly, $\mathrm{V}_{41}=(0.44,0.61,0.87)$ is a fuzzy triangular decision set allocated to applicant \#4 for 'communication skills'. The weighted fuzzy membership degrees of applicants with regard to the five main criteria are presented in Table 10, which includes the whole picture of the assessment process. The grades assigned by DMs are triangular fuzzified ranges. According to the weighted normalised fuzzy decision matrix, it is known that the elements are normalised as positive triangular fuzzy numbers, and their ranges are in the interval $[0,1]$. These ranges have to be de-fuzzified by determining the distance of each applicant from the ideal value.

We can then define the fuzzy positive-ideal solution (FPIS, A*) and fuzzy negative-ideal solution (FNIS, $A^{-}$) as follows:

$$
A^{*}=\left(\tilde{v}_{1}^{*}, \tilde{v}_{2}^{*}, \ldots, \tilde{v}_{n}^{*}\right), \quad A^{-}=\left(\tilde{v}_{1}^{-}, \tilde{v}_{2}^{-}, \ldots, \tilde{v}_{n}^{-}\right), \quad \text { where } \quad \tilde{v}_{j}^{*}=(1,1,1) \text { and }
$$

$\widetilde{v}_{j}=(0,0,0), j=1,2, \ldots, \mathrm{n}$. Hence,

$A^{*}=[(1,1,1),(1,1,1),(1,1,1),(1,1,1),(1,1,1)]$

$A^{-}=[(0,0,0),(0,0,0),(0,0,0),(0,0,0),(0,0,0)]$

The distance of each alternative applicant, $A_{i}(i=1,2, \ldots, m)$ from $A^{*}$ and $A^{-}$was calculated by Equations 10 and 11. 
Table 10: Fuzzy weighted decision matrix for ATC applicants

\begin{tabular}{|l|l|l|l|l|l|}
\hline \multirow{2}{*}{$\widetilde{V}_{i j}$} & \multicolumn{5}{|c|}{$\begin{array}{c}\text { The weighted fuzzy membership degrees of applicants } \\
\text { with regard to the main criteria }\end{array}$} \\
\cline { 2 - 6 } & \multicolumn{1}{|c|}{$\mathbf{C}_{\mathbf{1}}$} & \multicolumn{1}{|c|}{$\mathbf{C}_{\mathbf{2}}$} & \multicolumn{1}{|c|}{$\mathbf{C}_{\mathbf{3}}$} & \multicolumn{1}{c|}{$\mathbf{C}_{\mathbf{4}}$} & \multicolumn{1}{c|}{$\mathbf{C}_{\mathbf{5}}$} \\
\hline \multirow{2}{*}{$\mathbf{A}_{\mathbf{1}}$} & $(0.27,0.46$, & $(0.57,0.73$, & $(0.27,0.43$, & $(0.43,0.60$, & $(0.32$, \\
& $0.76)$ & $0.91)$ & $0.66)$ & $0.82)$ & $0.55,0.84)$ \\
\hline \multirow{2}{*}{$\mathbf{A}_{\mathbf{2}}$} & $(0.29,0.47$, & $(0.53,0.67$, & $(0.36,0.48$, & $(0.47,0.63$, & $(0.49$, \\
& $0.76)$ & $0.83)$ & $0.67)$ & $0.85)$ & $0.66,0.86)$ \\
\hline \multirow{2}{*}{$\mathbf{A}_{\mathbf{3}}$} & $(0.36,0.52$, & $(0.27,0.44$, & $(0.37,0.49$, & $(0.47,0.62$, & $(0.50$, \\
& $0.74)$ & $0.66)$ & $0.68)$ & $0.85)$ & $0.66,0.86)$ \\
\hline \multirow{2}{*}{$\mathbf{A}_{\mathbf{4}}$} & $(0.44,0.61$, & $(0.55,0.71$, & $(0.42,0.53$, & $(0.45,0.58$, & $(0.56$, \\
& $0.87)$ & $0.90)$ & $0.69)$ & $0.79)$ & $0.72,0.92)$ \\
\hline \multirow{2}{*}{$\mathbf{A}_{\mathbf{5}}$} & $(0.46,0.65$, & $(0.45,0.59$, & $(0.38,0.47$, & $(0.44,0.58$, & $(0.49$, \\
& $0.94)$ & $0.74)$ & $0.64)$ & $0.81)$ & $0.66,0.87)$ \\
\hline \multirow{2}{*}{$\mathbf{A}_{\mathbf{6}}$} & $(0.54,0.70$, & $(0.48,0.63$, & $(0.43,0.56$, & $(0.34,0.46$, & $(0.50$, \\
& $0.94)$ & $0.81)$ & $0.76)$ & $0.65)$ & $0.64,0.83)$ \\
\hline \multirow{2}{*}{$\mathbf{A}_{\mathbf{7}}$} & $(0.51,0.68$, & $(0.47,0.55$, & $(0.31,0.40$, & $(0.34,0.45$, & $(0.35$, \\
& $0.94)$ & $0.70)$ & $0.53)$ & $0.64)$ & $0.50,0.66)$ \\
\hline \multirow{2}{*}{$\mathbf{A}_{\mathbf{8}}$} & $(0.33,0.53$, & $(0.43,0.57$, & $(0.34,0.49$, & $(0.49,0.63$, & $(0.49$, \\
& $0.69)$ & $0.76)$ & $0.70)$ & $0.85)$ & $0.64,0.83)$ \\
\hline \multirow{2}{*}{$\mathbf{A}_{\mathbf{9}}$} & $(0.30,0.46$, & $(0.43,0.62$, & $(0.19,0.31$, & $(0.49,0.62$, & $(0.46$, \\
& $0.71)$ & $0.83)$ & $0.49)$ & $0.81)$ & $0.66,0.92)$ \\
\hline $\mathbf{A}_{\mathbf{1 0}}$ & $(0.53,0.68$, & $(0.53,0.67$, & $(0.37,0.46$, & $(0.35,0.45$, & $(0.46$, \\
& $0.94)$ & $0.84)$ & $0.61)$ & $0.62)$ & $0.62,0.78)$ \\
\hline
\end{tabular}

$$
\begin{aligned}
& d_{i}^{*}=\sum_{j=1}^{n} d\left(\tilde{v}_{i j}, \tilde{v}_{j}^{*}\right), \quad \mathrm{i}=1,2, \ldots, \mathrm{m}, \\
& d_{i}^{-}=\sum_{j=1}^{n} d\left(\tilde{v}_{i j}, \tilde{v}_{j}^{-}\right), \quad \mathrm{i}=1,2, \ldots, \mathrm{m} .
\end{aligned}
$$

In order for the TOPSIS method also to be used to deal with fuzzy MCDM problems, several extensions have been suggested. The simplest extension is to change a fuzzy MCDM problem into an exact one via de-fuzzification [21]. This can, however, cause some information loss, and it only gives an exact point estimate for the relative closeness of each alternative. Another extension is to define the Euclidean distance between any two fuzzy numbers as an exact value. For example, Chen [16] defined the Euclidean distance of two triangular fuzzy numbers as $\widetilde{v}_{i j}$ and $\widetilde{v}_{j}^{*}$; these have been applied in this study.

$$
\begin{aligned}
& d_{1}^{*}=\sqrt{\frac{(1-0.27)^{2}+(1-0.46)^{2}+(1-0.76)^{2}}{3}}+\ldots+\sqrt{\frac{(1-0.32)^{2}+(1-0.55)^{2}+(1-0.86)^{2}}{3}}=2.296 \\
& d_{1}^{*}=\sqrt{\frac{(0-0.27)^{2}+(0-0.46)^{2}+(0-0.76)^{2}}{3}}+\ldots+\sqrt{\frac{(0-0.32)^{2}+(0-0.55)^{2}+(0-0.86)^{2}}{3}}=3.012
\end{aligned}
$$

where $\mathrm{d}\left(d_{i}^{*}, d_{i}^{-}\right)$is the distance measurement between two fuzzy numbers. A closeness coefficient is defined to determine the ranking order of all applicants once the $d_{i}^{*}$ and $d_{i}^{-}$ of each alternative $A_{i}(i=1,2, \ldots, m)$ have been calculated. The closeness coefficient of each applicant is calculated by Equation 12 . 


$$
\begin{gathered}
C C_{i}=\frac{d_{i}^{-}}{d_{i}^{*}+d_{i}^{-}} \quad i=1,2, \ldots, \mathrm{m} . \\
C C_{1}=\frac{3.012}{2.296+3.012}=0.567, C C_{4}=\frac{3.326}{1.904+3.326}=0.636
\end{gathered}
$$

It is obvious that if an alternative $\left(A_{i}\right)$ is closer to the FPIS $\left(A^{*}\right)$, then it is further from FNIS $\left(A^{-}\right)$as $C C_{i}$ approaches 1 . Therefore, according to the closeness coefficient (CC), we determined the ranking order of all applicants and selected the best one among a set of alternatives. The ranking order of the ten applicants based on CCs is presented in Table 11.

Table 11: The Fuzzy weighted decision matrix for ATC applicants

\begin{tabular}{|c|c|c|c|c|}
\hline Applicants & FPIS $\left(d_{i}^{*}\right)$ & FNIS $\left(d_{i}^{-}\right)$ & $\begin{array}{c}\text { Similarity co- } \\
\text { efficient }\left(\mathbf{C C}_{\mathbf{i}}\right)\end{array}$ & $\begin{array}{c}\text { Ranking of } \\
\text { applicant }\end{array}$ \\
\hline $\mathbf{A}_{\mathbf{1}}$ & 2.296 & 3.012 & 0.567 & 7 \\
\hline $\mathbf{A}_{\mathbf{2}}$ & 2.135 & 3.105 & 0.593 & 3 \\
\hline $\mathbf{A}_{\mathbf{3}}$ & 2.274 & 2.929 & 0.563 & 8 \\
\hline $\mathbf{A}_{\mathbf{4}}$ & 1.904 & 3.326 & 0.636 & 1 \\
\hline $\mathbf{A}_{\mathbf{5}}$ & 2.092 & 3.144 & 0.600 & 2 \\
\hline $\mathbf{A}_{\mathbf{6}}$ & 2.170 & 3.161 & 0.592 & 4 \\
\hline $\mathbf{A}_{\mathbf{7}}$ & 2.421 & 2.747 & 0.532 & 9 \\
\hline $\mathbf{A}_{\mathbf{8}}$ & 2.199 & 3.011 & 0.578 & 6 \\
\hline $\mathbf{A}_{\mathbf{9}}$ & 2.538 & 2.877 & 0.531 & 10 \\
\hline $\mathbf{A}_{\mathbf{1 0}}$ & 2.144 & 3.038 & 0.586 & 5 \\
\hline
\end{tabular}

After the evaluation of fuzzy TOPSIS, the performance of applicants was obtained quantitatively and then evaluated by DEA for further assessment.

\subsection{DEA for quantitative assessment of ATCs}

DEA is a multi-player performance evaluation method that can assess the relative efficiency of each applicant within a set of decision-making units (DMUs). For the multi-inputs and multi-outputs processes, the efficiency score can be described as presented in Talluri [44].

In this study, a combination of the theory of fuzzy TOPSIS and DEA was applied to a real-life problem to solve a business problem. Although these two methodologies have been used extensively in the current literature, the applications of them have been carried out separately. The aim of combining fuzzy TOPSIS and DEA is to determine the ATC candidates who perform well in both fuzzy TOPSIS and DEA. The methodologies incorporated qualitative attributes for the evaluation of ATCS in more than one novel way by combining fuzzy TOPSIS and DEA. Fuzzy TOPSIS used qualitative attributes to rank the applicants. DEA used fuzzified attributes determined by TOPSIS to evaluate the candidates and answer the following question: to what extent do the required behaviours, such as awareness and motivation, actually reflect the applicant's communication, mathematical, and personal skills? The performance measurement of employing a correct applicant can be defined as the process of quantifying the efficiency of the action.

\section{Efficiency $=$ weighted sum of outputs / weighted sum of inputs}

The first accepted DEA model [45] was expressed mathematically in many sources. The DEA models developed later consider the slacks. The output oriented CCR (Charnes, Cooper, and Rhodes) model [45] can be written as follows:

$$
\operatorname{Max} \theta+\varepsilon\left(\sum_{i=1}^{m} S_{i j o}^{-}+\sum_{r=1}^{s} S_{i j o}^{+}\right)
$$




$$
\begin{aligned}
& \text { s.t. } \sum_{j=1}^{n} \lambda_{\mathrm{j}} \mathrm{x}_{\mathrm{ij}}+S_{i j o}^{-}=\mathrm{x}_{\mathrm{ijo}} \\
& \sum_{j=1}^{n} \lambda_{\mathrm{j}} \mathrm{y}_{\mathrm{rj}}-S_{r j o}^{+}=\theta \mathrm{y}_{\mathrm{rjo}} \\
& \lambda_{\mathrm{j}}, S_{i j o}^{-}, S_{r j o}^{+} \geq 0
\end{aligned}
$$

where for a set of $n$ applicants, for each applicant (DMU) there are $m$ inputs and s outputs.

$\mathrm{i}=1,2,3, \ldots, \mathrm{m}$,

$r=1,2,3, \ldots, s$,

$\mathrm{j}=1,2,3, \ldots, \mathrm{n}$.

$y_{r j}$ is the amount of output $r$ produced by applicant $j$,

$\mathrm{y}_{\mathrm{rjo}}$ is the amount of output $\mathrm{r}$ produced by applicant $\mathrm{j}_{\mathrm{o}}$ (i.e., the applicant who is being assessed),

$x_{i j}$ is the amount of input $i$ used by applicant $j$,

$x_{i j o}$ is the amount of input $i$ used by applicant $j_{0}, \lambda_{j}$ is the weight given to applicant $j$.

$S_{i j o}^{-}$and $S_{r j o}^{+}$represent the slack for input $i$ and the surplus for output $r$ respectively for applicant $j_{0}$. Note that $\varepsilon$ is an arbitrarily-selected small positive number added to ensure that slacks for all considered inputs and outputs are positive. In this case, the technical efficiency is achieved for each applicant if, and only if, both of the following conditions are fulfilled:

$$
\text { All slacks }=0 \text {, and efficiency score }=1 / \theta=1 .
$$

In this paper, an output-oriented CCR-DEA model was developed. The idea behind incorporating DEA within the fuzzy TOPSIS is to examine the extent to which each applicant is capable of converting their skills into the desired level of behaviours. Thus, as was shown in Figure 1, the communication, mathematical, and personal skills were considered as inputs for the proposed DEA model. On the other hand, the desired behaviours were the 'awareness' and the 'motivation' of the applicants; these were considered to be the outputs. By employing the average fuzzy numbers (shown in Table 10), the proposed DEA model was developed. The illustration of the proposed DEA model for the first applicant was expressed with respect to Equation 12, and is presented below.

$$
\begin{gathered}
\operatorname{Max} \theta+\varepsilon\left(S_{1}^{-}+S_{2}^{-}+S_{3}^{-}+S_{1}^{+}+S_{2}^{+}\right) \\
0.47 \lambda_{2}+0.52 \lambda_{3}+0.61 \lambda_{4}+0.65 \lambda_{5}+0.70 \lambda_{6}+0.68 \lambda_{7}+0.53 \lambda_{8}+0.46 \lambda_{9}+0.68 \lambda_{10}+S_{1}^{-}=0.46 \\
0.67 \lambda_{2}+0.44 \lambda_{3}+0.71 \lambda_{4}+0.59 \lambda_{5}+0.63 \lambda_{6}+0.55 \lambda_{7}+0.57 \lambda_{8}+0.62 \lambda_{9}+0.67 \lambda_{10}+S_{2}^{-}=0.73 \\
0.63 \lambda_{2}+0.62 \lambda_{3}+0.58 \lambda_{4}+0.58 \lambda_{5}+0.46 \lambda_{6}+0.45 \lambda_{7}+0.63 \lambda_{8}+0.62 \lambda_{9}+0.45 \lambda_{10}+S_{3}^{-}=0.60 \\
0.48 \lambda_{2}+0.49 \lambda_{3}+0.53 \lambda_{4}+0.47 \lambda_{5}+0.56 \lambda_{6}+0.40 \lambda_{7}+0.49 \lambda_{8}+0.31 \lambda_{9}+0.46 \lambda_{10}-S_{1}^{+}=\theta^{*} 0.43 \\
0.66 \lambda_{2}+0.66 \lambda_{3}+0.72 \lambda_{4}+0.66 \lambda_{5}+0.64 \lambda_{6}+0.50 \lambda_{7}+0.64 \lambda_{8}+0.66 \lambda_{9}+0.62 \lambda_{10}-S_{2}^{+}=\theta^{*} 0.55
\end{gathered}
$$

The ten applicants were assessed by the proposed DEA model in order to answer the following question: To what extent do the required behaviours, such as awareness and motivation, actually reflect the applicant's communication, mathematical, and personal skills? The average fuzzy numbers for the identified inputs and outputs for each applicant were obtained from Table 10 and used to develop the DEA. The Frontier Analyst Software was used for the model development. When the finding is compared with the efficiency of applicants (for Efficiency Score =1), it is obvious that the inefficient applicants could use their skills better and convert them into the desired level of output measures (awareness and motivation). The results of DEA are presented in Table 12, indicating that five 
applicants were inefficient: $A_{1}, A_{5} . A_{7}, A_{8}$, and $A_{10}$, with respective scores of $0.926,0.942$, $0.843,0.966$, and 0.993. As illustrated in Table 12, awareness and motivation for $A_{1}$ are supposed to be 8 per cent and 15 per cent more than the current situation, respectively. The results also showed that, for applicant \#1 $\left(A_{1}\right), 11$ per cent of their mathematical skills are not used. Similarly, all inefficient applicants have a potential to improve their input and output measures, as shown in Table 12.

Table 12: The results of the proposed DEA models

\begin{tabular}{|c|c|c|c|c|c|c|}
\hline \multicolumn{7}{|c|}{ Potential improvement for input and output criteria } \\
\hline \multicolumn{2}{|c|}{} & \multicolumn{3}{c|}{ Inputs } & \multicolumn{2}{c|}{ Outputs } \\
\hline Applicants & $\begin{array}{c}\text { Efficiency } \\
\text { score }\end{array}$ & $\begin{array}{c}\text { Communication } \\
\text { skills }\end{array}$ & $\begin{array}{c}\text { Mathematical } \\
\text { Skills }\end{array}$ & $\begin{array}{c}\text { Personal } \\
\text { skills }\end{array}$ & Awareness & Motivation \\
\hline $\mathbf{A}_{\mathbf{1}}$ & 0.926 & $\ldots$ & -0.11 & $\ldots$ & 0.08 & 0.15 \\
\hline $\mathbf{A}_{\mathbf{2}}$ & 1 & $\ldots$ & $\ldots$ & $\ldots$ & $\ldots$ & $\ldots$ \\
\hline $\mathbf{A}_{\mathbf{3}}$ & 1 & $\ldots$ & $\ldots$ & $\ldots$ & $\ldots$ & $\ldots$ \\
\hline $\mathbf{A}_{\mathbf{4}}$ & 1 & $\ldots$ & $\ldots$ & $\ldots$ & $\ldots$ & $\ldots$ \\
\hline $\mathbf{A}_{\mathbf{5}}$ & 0.942 & $\ldots$ & $\ldots$ & $\ldots$ & 0.19 & 0.06 \\
\hline $\mathbf{A}_{\mathbf{6}}$ & 1 & $\ldots$ & $\ldots$ & $\ldots$ & 0.26 & 0.18 \\
\hline $\mathbf{A}_{\mathbf{7}}$ & 0.843 & -0.09 & $\ldots$ & $\ldots$ & 0.03 & 0.06 \\
\hline $\mathbf{A}_{\mathbf{8}}$ & 0.966 & $\ldots$ & $\ldots$ & $\ldots$ & $\ldots$ & $\ldots$ \\
\hline $\mathbf{A}_{\mathbf{9}}$ & 1 & $\ldots$ & -0.08 & $\ldots$ & 0.18 & $\ldots$ \\
\hline $\mathbf{A}_{\mathbf{1 0}}$ & 0.993 & $\ldots$ & $\ldots$ & & $\ldots$ \\
\hline
\end{tabular}

Table 13 presents the final ranking of the applicants. The applicants' fuzzy TOPSIS ranking, the efficiency scores of DEA, the final scores, and ranking of applicants were determined. Table 13 also presents the final scores that resulted from multiplying the column of $\left(\mathrm{CC}_{\mathrm{i}}\right)$ by the column of the Efficiency Score. The overall results showed that applicant \#4 $\left(A_{4}\right)$ is using the criteria the best, and is still ranked first. However, the order of the other applicants changed as a result of the DEA application. Similarly, Figure 3 depicts the ranking of applicants, where the superiority of applicant \#4 is obvious.

Table 13: Final ranking of applicants

\begin{tabular}{|c|c|c|c|c|c|c|}
\hline $\begin{array}{c}\text { Applic } \\
\text { ants }\end{array}$ & $\begin{array}{c}\text { Similarity co- } \\
\text { efficient }\left(\mathbf{C C}_{\mathbf{i}}\right)\end{array}$ & $\begin{array}{c}\text { Fuzzy TOPSIS } \\
\text { ranking }\end{array}$ & $\begin{array}{c}\text { Efficiency } \\
\text { Score of DEA }\end{array}$ & $\begin{array}{c}\text { Final } \\
\text { score }\end{array}$ & $\begin{array}{c}\text { Final } \\
\text { ranking }\end{array}$ & $\begin{array}{c}\text { Change in } \\
\text { ranking }\end{array}$ \\
\hline $\mathbf{A}_{\mathbf{1}}$ & 0.567 & 7 & 0.926 & 0.525 & 9 & -2 \\
\hline $\mathbf{A}_{\mathbf{2}}$ & 0.593 & 3 & 1.000 & 0.593 & 2 & +1 \\
\hline $\mathbf{A}_{\mathbf{3}}$ & 0.563 & 8 & 1.000 & 0.563 & 6 & +2 \\
\hline $\mathbf{A}_{\mathbf{4}}$ & 0.636 & 1 & 1.000 & 0.636 & 1 & No Change \\
\hline $\mathbf{A}_{\mathbf{5}}$ & 0.600 & 2 & 0.942 & 0.565 & 5 & -3 \\
\hline $\mathbf{A}_{\mathbf{6}}$ & 0.592 & 4 & 1.000 & 0.592 & 3 & +1 \\
\hline $\mathbf{A}_{\mathbf{7}}$ & 0.532 & 9 & 0.843 & 0.448 & 10 & -1 \\
\hline $\mathbf{A}_{\mathbf{8}}$ & 0.578 & 6 & 0.966 & 0.558 & 7 & -1 \\
\hline $\mathbf{A}_{\mathbf{9}}$ & 0.531 & 10 & 1.000 & 0.531 & 8 & +2 \\
\hline $\mathbf{A}_{\mathbf{1 0}}$ & 0.586 & 5 & 0.993 & 0.582 & 4 & +1 \\
\hline
\end{tabular}



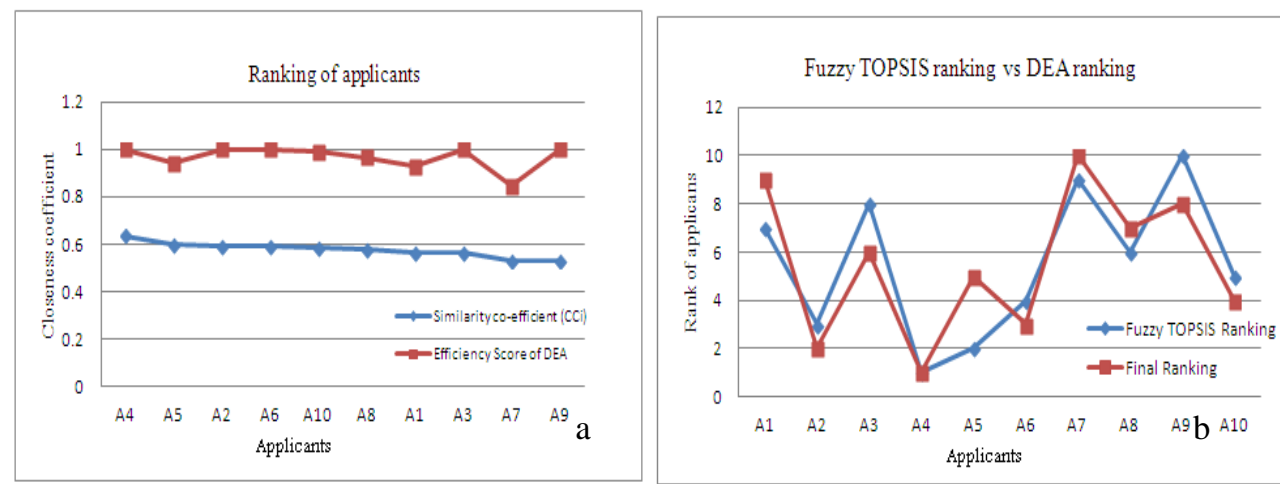

Figure 3: The ranking of applicants: (a) similarity coefficient, (b) DEA ranking

\section{CONCLUSION}

The objective of this study was to propose a method to determine the most eligible ATCs for the Saudi air traffic control system. The controller selection problem is usually very complex because many important criteria have to be considered, as identified in Figure 1, and the selection system needs to be error-free and reliable. The proposed method in this study is a hybrid approach including fuzzy decision tree and fuzzy TOPSIS method with DEA. This approach is unique for the solution of such real-life problems. The fuzzy TOPSIS approach de-fuzzified the outcomes and produced exact relative closeness to provide possible solutions to a fuzzy MCDM problem. In fuzzy MCDM problems, criteria values and the relative weights are usually characterised by fuzzy numbers, which brings flexibility in decision-making. The application of the DEA contributed to the fuzzy TOPSIS model by adding a pivotal dimension to the assessment process. It can be concluded that the final decision was significantly influenced by the incorporated DEA model. As they appear in Figure 12, the results of the proposed DEA model clearly indicate the efficiency score of each applicant. With these scores, decision-makers can easily eliminate an individual candidate, or a group of candidates, who are incompetent. The final ranking of applicants is presented in Figure 13. From this ranking, the decision-makers can eliminate the applicants below a certain level. Thus a decision support system might be developed to improve the efficiency of the decision-making process for selecting ATCs.

\section{REFERENCES}

[1] Hough, L.M. \& Oswald, F.L. 2000. Personnel selection: Looking toward the future, remembering the past. Annual Review of Psychology, 51, pp 631-664.

[2] Kaynak, T. 2002. Human resources management. Istanbul: Nobel Press.

[3] Dereli, T., Durmusoglu, A., Seckiner, S.U. \& Avlanmaz, N. 2010. A fuzzy approach for personnel selection process. Turkish J ournal of Fuzzy Systems, 1, pp 126-140.

[4] Karsak, E.E. 2001. Personnel selection using a fuzzy MCDM approach based on ideal and antiideal solutions. In Multiple criteria decision-making in the new millennium, Berlin, pp 425-432.

[5] Gatewood, R.D. \& Feild, H.S. 1994. Human resource selection. 3rd edition, Chicago: The Dryden Press. University of Chicago Press

[6] Sousa, J.M.C. \& Kaymak, U. 2002. Fuzzy decision-making in modeling and control. In World scientific series in robotics and intelligent systems. New York: E-Publishing Inc.

[7] Chen, C.T., Lin, C.T. \& Huang. S.F. 2006. A fuzzy approach for supplier evaluation and selection in SCM. International J ournal of Product Economics, 102, pp 289-301.

[8] Chu, T.C. 2002. Facility location selection using fuzzy TOPSIS under group decisions. International J ournal of Uncertainty Fuzziness and Knowledge-Based Systems, 10, pp 687-701.

[9] Abo-Sinna, M.A. \& Amer, A.H. 2005. Extensions of TOPSIS for multi-objective large-scale nonlinear programming problems. Applied Math. and Comp., 16, pp 243-256.

[10] Banker, R.D., Charnes, A. \& Cooper, W.W. 1984. Some models for estimating technical and scale inefficiencies in data envelopment analysis. Management Science, 30, pp 1078-1092. 
[11] Zeydan, M. \& Çolpan, C. 2009. A new decision support system for performance measurement using combined fuzzy TOPSIS/ DEA approach. International J ournal of Production Research, 47, pp 4327-4349.

[12] Huang, S., Yilin, C. \& Chiu, N.H. 2006. Fuzzy decision tree approach for embedding risk assessment information into software cost estimation model. Journal of Information Science and Engineering, 22, pp 297-313.

[13] Mitra, S., Konwar, K. \& Pal, S.K. 2002. Fuzzy decision tree, linguistic rules and fuzzy knowledgebased network: Generation and evaluation. IEEE Transactions on Systems, Man, and Cybernetics Part C: Applications and Reviews, 32(4), pp 328-339.

[14] Tsaur, S.H., Chang, T.Y. \& Yen, C.H. 2002. The evaluation of airline service quality by fuzzy MCDM. Tourism Management, 23, pp 107-115.

[15] Chu, T.C. \& Lin, Y.C. 2003. A fuzzy TOPSIS method for robot selection. International J ournal of Advanced Manufacturing Technology, 21, pp 284-290.

[16] Chen, C.T. 2000. Extensions of the TOPSIS for group decision-making under fuzzy environment, Fuzzy Sets and Systems, 114, pp 1-9.

[17] J iang, J ., Chen, Y., Chen, W. \& Yang, K.W. 2011. TOPSIS with fuzzy belief structure for group belief multiple criteria decision making. Expert Systems with Applications, 38, pp 9400-9406.

[18] Saghafian, S. \& Hejazi S. R. 2005. MCDM Using a modified fuzzy TOPSIS procedure. Proceedings of the 2005 International Conference on Computational Intelligence for Modelling, CIMCA-IAWTIC, 2005.

[19] Deng, H., Yeh C.-H. \& Willis, R.]. 2000. Inter-company comparison using modified TOPSIS with objective weights. Computers \& Operations Research, 27, pp 963-973.

[20] Balli, S. \& Korukoglu. S. 2009. Operating system selection using fuzzy AHP and TOPSIS methods. Mathematical \& Computational Applications, 14, pp 119-130.

[21] Wang, T.C. \& Lee, H.D. 2009. Developing a fuzzy TOPSIS approach based on subjective weights and objective weights. Expert Systems with Applications, 36, pp 8980-8985.

[22] Dagdeviren, M., Yavuz, S. \& Kilinc, N. 2009. Weapon selection using the AHP and TOPSIS methods under fuzzy environment. Expert Systems with Applications, 36, pp 8143-8151.

[23] Ertugrul, I. \& Karakasoglu. N. 2009. Performance evaluation of Turkish cement firms with fuzzy analytic hierarchy process and TOPSIS methods. Expert Systems with Applications, 36, pp 702715.

[24] Salgado, J.F. 1997. The five factor model of personality and job performance in the European Community. J ournal of Applied Psychology, 82, pp 30-43.

[25] Ma, L.C. $\&$ Li, H.L. 2008. A fuzzy ranking method with range reduction techniques. European J ournal of Operational Research, 184, pp 1032-1043.

[26] J essop, A. 2004. Minimally biased weight determination in personnel selection. European J ournal of Operational Research, 153, pp 433-444.

[27] Griffeth, R.W., Hom, P.W. \& Gaertner, S. 2000. A meta-analysis of antecedents and correlates of employee turnover: Update, moderator tests, and research implications for the next millennium. J ournal of Management, 26, pp 463-488.

[28] Singh, R., \& Mohanty, M. 2012. Impact of training practices on employee productivity: A comparative study. Inter-science Management Review (IMR), 2, pp 2231-1513.

[29] Zhu, C.J ., \& Dowling, P.J . 2002. Staffing practices in transition: Some empirical evidence from China. International J ournal of Human Resource Management, 13, pp 569-597.

[30] Zeydan, M., Çolpan, C. \& Çobanoglu, C. 2011. A combined methodology for supplier selection and performance evaluation. Expert Systems with Applications, 38, pp 2741-2751.

[31] Guerra, M., de Souza, A.A. \& Moreira, D.R. 2012. Performance analysis: A study using DEA in 26 Brazilian hospitals. J ournal of Health Care Finance, 38, pp 19-29.

[32] Paradi, J.C., Rouatt, S. \& Zhu, H. 2011. Two-stage evaluation of bank branch efficiency using data envelopment analysis. Omega, 39, pp 99-109.

[33] Wang, Y.M., Luo, Y. \& Liang, L. 2009. Fuzzy data envelopment analysis based upon fuzzy arithmetic with an application to performance assessment of manufacturing enterprises. Expert Systems with Applications, 36, pp 5205-5211.

[34] Mohammadi, A., Rafiee, S., Mohtasebi, S.S., Mousavi Avval, S.H. \& Rafiee, H. 2011. Energy efficiency improvement and input cost saving in kiwifruit production using data envelopment analysis approach. Renewable Energy, 36, pp 2573-2579.

[35] Partovi, F.Y. 2011. Corporate philanthropic selection using data envelopment analysis. Omega, 39, pp 522-527. 
[36] Chang, P.T. \& Lee, J.H. 2012. A fuzzy DEA and knapsack formulation integrated model for project selection. Computers \& Operations Research, 39, pp 112-125.

[37] Kuo, R.J. \& Lin, Y.J. 2012. Supplier selection using analytic network process and data envelopment analysis. International J ournal of Production Research, 50, pp 2852-2863.

[38] Lin, H.T. 2010. Personnel selection using analytic network process and fuzzy data envelopment analysis approaches. Computers \& Industrial Engineering, 59, pp 937-944.

[39] Azadeh, A., Saberi, M., Moghaddam, R.T. \& Javanmardi, L. 2011. An integrated data envelopment analysis-artificial neural network-rough set algorithm for assessment of personnel efficiency. Expert Systems with Applications, 38, pp 1364-1373.

[40] Ramanathan, R. \& Yunfeng, J. 2009. Incorporating cost and environmental factors in quality function deployment using data envelopment analysis. Omega, 37, pp 711-723.

[41] Amado, C.A., Santos, S.P. \& Marques, P.M. 2012. Integrating the data envelopment analysis and the balanced scorecard approaches for enhanced performance assessment. Omega, 40, pp 390403.

[42] Chen, Y., Li, K.W., Xu, H. \& Liu, S. 2009. A DEA-TOPSIS method for multiple criteria decision analysis in emergency management. J ournal of Systems Science and Systems Engineering, 18, pp 489-507.

[43] Lotfi, F.H., Fallahnejad, R. \& Navidi, N. 2011. Ranking efficient units in DEA by using TOPSIS method. Applied Mathematical Sciences, 5, pp 805-815.

[44] Talluri, S. 2000. DEA: models and extensions. Decision Line, 31, pp 8-11.

[45] Charnes, A., Cooper, W.W. \& Rhodes, E. 1978. Measuring the efficiency of decision making units. European J ournal of Operational Research, 2, pp 429-444. 